\title{
Research Article \\ Growth and yield performance of oyster mushroom (Pleurotus ostreatus) on different substrates
}

\author{
${ }^{1}$ Pawan Dhakal*, ${ }^{1}$ Amrit Pokhrel, ${ }^{1}$ Anju Bista, ${ }^{1}$ Kabita Shah, and ${ }^{3}$ Basistha Acharya,and ${ }^{3}$ Jiban Shrestha \\ ${ }^{1}$ Prithu Technical College, TU, Bangaun, Dang, Nepal \\ ${ }^{2}$ Nepal Agricultural Research Council, RARS, Khajura, Banke, Nepal \\ ${ }^{3}$ Nepal Agricultural Research Council, Agriculture Botany Division, Khumaltar, Lalitpur, Nepal \\ *Correspondance: pawandhakal21142@gmail.com
}

Received: 29 April 2020 / Accepted: 08 June 2020

URL:https://doi.org/10.38112/agw.2020.v08i01.001

\begin{abstract}
Oyster mushroom (Pleurotus oestratus) has outstanding flavor and taste with fan shaped pileus which is rich source of both macro and micro nutrients. It is of paramount importance to choose appropriate substrates in a given place to grow oyster mushroom successfully. The experiment was conducted at Bangaun, Lamahi, Dang, Nepal during 2018-19 to study the growth performance of oyster mushroom on locally available substrates as well as to find out the best substrate. The substrates used in the experiment were lentil straw, rice straw, wheat straw, maize stover, maize cob, along with the mix ratio of corn cob 1:3 with these substrates under factorial completely randomized design (CRD) design with four replications during winter season with an average daily temperature of $12-21^{\circ} \mathrm{C}$ and $\mathrm{RH}$ ranging from 80 to $90 \%$. Among the tested substrate composition, significantly the lowest days (17.5 days) to complete spawn running was recorded on maize cob followed by lentil straw ( 22.5 days) while highest days ( 30.75 days) was required to complete spawn running on rice straw. The lowest time (25.50 days) for first fruiting initiation, the lowest time (33 days) for harvesting and the highest yield $(2.47 \mathrm{~kg})$ was revealed by lentil straw. The highest pileus diameter $(6.81 \mathrm{~cm})$ was recorded on wheat straw followed by rice and maize cob mix at 3:1 ratio $(6.58 \mathrm{~cm})$. Lentil straw was found the best substrate and rice straw mix with maize cob was more efficient as compared to rice straw only for the production of Pleurotus ostreatus mushroom.
\end{abstract}

Keywords: Oyster mushroom, substrates, straw, spawn, yield

\section{Introduction}

Mushrooms are a good source of protein, vitamins and minerals (Kimenju et al., 2009.) and their protein is intermediate between that of animals and vegetables (Kurtzman, 1976). Mushrooms have played an important role as a human food due to its nutritional and medicinal properties. Oyster mushrooms are one kind of edible saprophytic fungi growing on dead organic matters of vegetative origin belonging to the genus Pleurotus under the class Basidiomycetes (Mondal et al., 2010). They are having outstanding flavor and taste with fan shaped pileus which is rich source of both macro and micro nutrients. Oyster mushroom has no starch, low sugar content and high amount of fiber, hence it serves as the least fattening food (Oei, 1996). Oyster mushrooms is rich in nutitional value has with dried protein $(25-50 \%)$, fat $(2-5 \%)$, sugars (17-47\%), mycocellulose (7-38\%) and minerals (potassium, phosphorus, calcium, sodium) of about 812\% (Sher, 2010). Recently, its importance and nutritive value has been realized and well utilized in human consumption diet. Livelihood can be improved because the demand of mushroom has been increasing due to increasing population, market expansions and changing of consumer behavior (Celikand and Pekker, 2009).There are several species of Pleurotus identified in the world and suitable for cultivation, some of them are Pleurotus ostreatus, P. florida P. sajorcaju, P.eryngii (Nadir et al., 2016). However, the most important cultivated species is Pleurotus ostreatus, being easier to cultivate, favorable to grow on different kinds of agriculture by products i.e. rice straw, sawdust, wheat straw, corn silk, sugarcane bagasase and other plant fibers having cellulose content (Ju, 1994; Kong, 2004). Several species of oyster mushroom can be grown on lignocelluloses, forest byproducts and agricultural wastes (Chang, 1999). Cultivation of oyster mushroom with agricultural residues, such as rice and wheat straw is a value added process to convert these materials into human food (Pokhrel et al., 2013). Agricultural substrates such as paddy straw, vegetable residues, maize stalks and cotton waste are utilized for cultivation of oyster mushroom (Hassan et al., 2011).Substrates having high levels of nitrogen and carbohydrate contents are categorized as ideal for mushroom growth (Khare et al., 2010). Ecological requirements of oyster mushrooms vary at the various stages of growing period. The growth of oyster mushroom requires high humidity $(80-90 \%)$ and high 
temperature $\left(25-30^{\circ} \mathrm{C}\right)$ for the vegetative growth called spawn running and lower temperature $\left(18-25^{\circ} \mathrm{C}\right)$ with high humidity 80 to $95 \%$ during fruit body formation, (Onyango et al., 2011 and Nadir et al, 2016). Oyster mushroom can be grown on various agricultural wastes with the use of different technologies, however in Nepal rice straw is the most common. Majority of farmer use rice straw for oyster mushroom production as and they are not familiar with efficiency and methods of Pleurotus mushroom production using other agro bi-products like lentil straw, wheat straw, maize stover, maize cob etc. During the main harvesting period, corn cobs and stalks are in abundance and farmers dispose of them by burning. If grounded corn cob can support the growth of oyster mushroom, then it would serve as a cheap source of substrate for mushroom growers. The grounded form of corncob is very firm and retains good amount of moisture to make it a plausible alternative to saw dust (Buah et al., 2010). The experiment was conducted on rice straw, wheat straw, lentil straw, maize stover, maize cob along with the mix ratio of corn cob 1:3 with these substrates with a view to determine the cheapest substrate with best yield performance. This study we will be able to suggest

Table 1: Detail of treatments and composition best alternative substrates other than single rice straw substrate.

\section{Materials and methods}

\section{Experimental site}

The experiment was conducted in Mushroom production house of Prithu Technical College, Bangaun, Dang, Nepal. Geographically the experimental site was located at latitude $27.9904^{\circ} \mathrm{N}$ and longitude $82.3018^{\circ} \mathrm{E}, 567$ masl. The experiment was conducted during November 30, 2018 to February 27, 2019.

\section{Spawn Collection}

The oyster mushroom Pleurotus oestratus was used in the experiment and spawn for the conduction of experiment was collected from the Regional Agricultural Research Station, NARC, Khajura, Banke Nepal. All together 15 packets of $250 \mathrm{~g}$ sized spawn was collected.

Preparation of Substrates

The experiment was laid by using Factorial Completely Randomized design having four replications.

\begin{tabular}{ccc}
\hline S. N. & Treatments & Composition \\
\hline 1 & Substrate -1 & Rice straw \\
2 & Substrate -2 & Lentil straw \\
3 & Substrate -3 & Maize stover \\
4 & Substrate -4 & Wheat straw \\
5 & Substrate -5 & Maize cob \\
6 & Substrate -6 & Rice straw : Maize cob $=3: 1$ \\
7 & Substrate -7 & Lentil straw: Maize cob $=3: 1$ \\
8 & Substrate -8 & Maize stover: Maize cob $=3: 1$ \\
9 & Substrate -9 & Wheat straw : Maize cob $=3: 1$ \\
\hline
\end{tabular}

The required substrates like corn cobs, wheat straw, rice straw, lentil straw, maize stover, were collected from farms around the Prithu Technical College, Bangaun. Corn cob was reduced into small sizes using a hammer where as remaining other substrates were chopped into small pieces of 1-2 inch with a sickle after sun drying. The substrate composition was solely the rice straw, wheat straw, lentil straw, maize stover along with the mix ratio of corn cobs in 1:3 with all these substrates each of 6 $\mathrm{kg}$.

The substrate materials were washed thoroughly with clean water and soaked for 30 minutes and excess water was allowed to drain down so that water didn't ooze out when squeezed with hand.

\section{Sterilization of substrates}

Each substrate was individually sterilized by steam using metallic drum for 1 to $2 \mathrm{hrs}$ and were allowed to cool to normal temperature or $20-25^{\circ} \mathrm{c}$, which was then filled into plastic bags of size $16^{\prime}$ 'x $24^{\prime}$ ' making four layers.

\section{Spawning and filling the substrates}

The different substrate composition were mixed thoroughly on sterilized cemented floor and filled in to the polypropylene bags $(16 \times 24 \mathrm{~cm})$. Each mushroom ball was prepared by filling $6 \mathrm{~kg}$ weight of the substrates. Spawning was done at periphery of each layer with $20 \mathrm{~g}$ of spawn and altogether four spawn layers was made alternately with substrates maintaining $5 \mathrm{~cm}$ gap. Top layer spawning was also done on each mushroom ball. 
After completion of spawning the bags were tied at the mouth and for aeration few holes were made around the periphery of plastic bag with a pencil size thicken wooden stick. The bags were then marked treatment wise with a permanent marker.

\section{Incubation}

The experiment was laid out in factorial completely randomized design (CRD) with nine treatments and 4 replications. Thus, there were altogether 36 bags. The mushroom balls were place randomly in a floor of a sterilized dark room for incubation. The bags were incubated until mycelium had fully colonized the substrate.

\section{Fruiting}

After complete colonization the mushroom balls were taken to the fruiting room. The thickening of the mycelia in the bags and colonization of the bags was an indication for the completion of the spawn run. After the substrates were fully colonized with mycelium, the plastics were removed and placed in dispersed light with well ventilated condition. Watering was done twice a day to maintain high relative humidity $(80-85 \%)$, low temperature (22$27^{\circ} \mathrm{C}$ ) at culture for the development of fruiting body. After complete fruiting, harvesting was done in different flushes.

\section{Data collection and statistical analysis}

Data on time required for spawn running, primordial initiation, harvesting, stalk length, stalk diameter, pileus diameter, and biological yield were recorded. The stipe length, stipe diameter, pileus diameter was measured as an average of five sample taken randomly from each treatment during harvest time. Observed data were then analyzed by R- Studio. Analysis of variance (ANOVA) was used to test differences among the treatments and means were separated using Duncan's multiple range test (DMRT) at the $5 \%$ level of significance (Gomez and Gomez, 1984).

\section{Result}

Nine different types of substrates along with mix ratio were compared with respect to production of oyster mushroom. The substrates used in this studies exhibited variation in spawn run, days to harvests, stipe length and diameter, pileus diameter and total yield.

Time (days) required for complete colonization, primordia formation and harvesting

Treatment means are separated by Duncan's Multiple Range Test (DMRT) and the columns represented by the same letter (s) are not significantly different among each other at $5 \%$.

Analysis of variance (ANOVA) revealed highly significant results among the tested substrates $(\mathrm{p} \leq 0.05)$ in colonization duration, first fruiting duration and first harvest duration. Days to complete colonization ranged from 17 days to 30 days on different substrates. Significantly the lowest days (17.5 days) to complete spawn running was recorded on maize cob followed by lentil straw (22.5 days) while highest day (30.75 days) was required to complete spawn running on rice straw followed by maize straw (29.50 days).

Table 2: Effect of different substrates on first colonization duration, first fruiting duration, first harvesting duration of oyster mushroom

\begin{tabular}{llll}
\hline Substrates & $1^{\mathrm{st}}$ colonization duration(days) & $1^{\mathrm{st}}$ Fruiting duration(days) & $1^{\text {st } H a r v e s t i n g ~ d u r a t i o n}($ days) \\
\hline Maize cob & $17.5^{\mathrm{g}}$ & $42.75^{\mathrm{a}}$ & $58.25^{\mathrm{a}}$ \\
Wheat straw & $33^{\mathrm{a}}$ & $37.50^{\mathrm{b}}$ & $45.50^{\mathrm{bc}}$ \\
Wheat mix & $28^{\mathrm{d}}$ & $34.25^{\mathrm{bc}}$ & $48.00^{\mathrm{b}}$ \\
Rice straw & $30.75^{\mathrm{b}}$ & $33.75^{\mathrm{c}}$ & $45.50^{\mathrm{bc}}$ \\
Maize straw & $29.50^{\mathrm{c}}$ & $33.00^{\mathrm{cd}}$ & $46.50^{\mathrm{b}}$ \\
Rice mix & $28^{\mathrm{d}}$ & $32.75^{\mathrm{cd}}$ & $42.75^{\mathrm{c}}$ \\
Maize straw mix & $27^{\mathrm{d}}$ & $30.00^{\mathrm{de}}$ & $37.25^{\mathrm{d}}$ \\
Lentil mix & $24^{\mathrm{e}}$ & $27.25^{\mathrm{ef}}$ & $38.75^{\mathrm{d}}$ \\
Lentil straw & $22.5^{\mathrm{f}}$ & $25.50^{\mathrm{f}}$ & $33.00^{\mathrm{e}}$ \\
\hline Grand Mean & 26.69 & 32.97 & 43.94 \\
CD(P $\leq 0.05)$ & 1.04 & 3.40 & 3.62 \\
CV\% & 2.67 & 7.10 & 5.68 \\
F test & $* *$ & $* *$ & $* *$ \\
\hline$* *=$ Significant at 1\% level, Mean values within the same column that bear different superscript letters are significantly \\
different $\alpha<0.05)$, CV Coefficient of variation and CD= Critical difference.
\end{tabular}


The fruiting duration was also statistically significant to the different substrate composition. Significantly lowest time (25.50 days) for first fruiting initiation was recorded on lentil straw followed by lentil and maize cob mixture 3:1 (27.25 days) while the highest time (42.75 days) for first fruiting initiation was found in maize cob followed by wheat straw ( 37.50 days).

The harvesting duration was also statistically significant to the different substrate composition. The lowest time (33 days) for harvesting was recorded from lentil straw followed by maize straw and maize cob mixture 3:1 (37.25 days) while the highest days for harvesting was recorded on maize cob (58.25 days) followed by wheat and maize cob mixture 3:1 (48 days).
Effect of different substrates on yield of oyster mushroom

Analysis of variance showed highly significant result among the tested substrates $(\mathrm{p} \leq 0.05)$ for final yield. The yield was measured during each harvest and the total yield was calculated finally. It was found highest from lentil straw $(2.47 \mathrm{~kg})$ followed by rice and maize cob mixture 3:1 $(1.74 \mathrm{~kg})$ while the lowest yield was observed in maize cob $(0.16 \mathrm{~kg})$ followed by wheat and maize cob mixture $3: 1(1.01 \mathrm{~kg})$ under similar environment and cultural practices among other substrates.

Table 3: Effect of different substrates on yield of oyster mushroom

\begin{tabular}{ll}
\hline Treatments & Yield $(\mathrm{kg})$ \\
\hline Lentil straw & $2.47^{\mathrm{a}}$ \\
Rice mix & $1.74^{\mathrm{b}}$ \\
Maize Stover mix & $1.52^{\mathrm{bc}}$ \\
Wheat straw & $1.46^{\mathrm{bc}}$ \\
Rice straw & $1.43^{\mathrm{bc}}$ \\
Lentil mix & $1.15^{\mathrm{bc}}$ \\
Maize Stover & $1.15^{\mathrm{bc}}$ \\
Wheat mix & $1.01^{\mathrm{c}}$ \\
Maize cob & $0.16^{\mathrm{d}}$ \\
\hline Grand Mean & 1.34 \\
$\mathrm{CD}(\mathrm{P} \leq 0.05)$ & 0.59 \\
$\mathrm{CV}(\%)$ & 2.05 \\
$\mathrm{~F}$ test & $* *$ \\
\hline$* *=$ Significant at 1\% level, Mean values within the same column that bear different superscript letters are significantly \\
different $\alpha<0.05)$ CV=Coefficient of variation and CD $=$ Critical difference
\end{tabular}

\section{Effect of different substrates on pileus diameter of oyster mushroom}

The diameter of the pileus differed significantly on different substrates. The pileus diameter was measured as an average of five samples taken randomly from each treatment. The highest pileus diameter was recorded on wheat straw $(6.81 \mathrm{~cm})$ followed by rice and maize cob mix at $3: 1$ ratio $(6.58 \mathrm{~cm})$ and lentil straw $(6.57 \mathrm{~cm})$ while the lowest diameter was recorded on maize cob $(3.87 \mathrm{~cm})$ under similar environment and cultural practices among other substrates. 
Dhakal et al.

Table 4: Effect of different substrate on pileus diameter of oyster mushroom

\begin{tabular}{ll}
\hline Treatments & Cap diameter $(\mathrm{cm})$ \\
\hline Wheat straw & $6.81^{\mathrm{a}}$ \\
Rice mix & $6.58^{\mathrm{a}}$ \\
Lentil straw & $6.57^{\mathrm{a}}$ \\
Rice straw & $6.41^{\mathrm{a}}$ \\
Wheat mix & $6.15^{\mathrm{ab}}$ \\
Maize Stover & $5.47^{\mathrm{bc}}$ \\
Lentil mix & $5.39^{\mathrm{bc}}$ \\
Maize Stover mix & $4.89^{\mathrm{c}}$ \\
Maize cob & $3.87^{\mathrm{d}}$ \\
\hline Grand Mean & 5.77 \\
CD(P $\leq 0.05)$ & 0.83 \\
CV $(\%)$ & 9.97 \\
$\mathrm{~F}$ test & $* *$ \\
\hline$* *=$ Significant at 1\% level, Mean values within the same column that bear different superscript letters are significantly \\
different $\alpha<0.05)$, CV=Coefficient of variation and CD=Critical difference
\end{tabular}

Effect of different substrates on stipe diameter of oyster mushroom

Analysis of variance showed highly significant result among the tested substrates $(\mathrm{p} \leq 0.05)$ for stipe diameter. The stipe diameter was measured as an average of five samples taken randomly from each treatment. In case of stipe diameter, it was found highest from wheat and maize cob mixture $3: 1(1.65 \mathrm{~cm})$ followed by wheat straw $(1.59$ $\mathrm{cm})$ while, lowest stipe diameter was observed in maize cob $(0.75 \mathrm{~cm})$ under similar environment and cultural practices among other substrates.

Table 5: Effect of different substrates on stipe diameter of oyster mushroom

\begin{tabular}{|c|c|}
\hline Treatments & Stipe diameter $(\mathrm{cm})$ \\
\hline Wheat mix & $1.65^{\mathrm{a}}$ \\
\hline Wheat straw & $1.59^{\mathrm{ab}}$ \\
\hline Lentil straw & $1.43^{\mathrm{bc}}$ \\
\hline Rice mix & $1.36^{\mathrm{cd}}$ \\
\hline Lentil mix & $1.19^{\mathrm{de}}$ \\
\hline Rice straw & $1.11^{\mathrm{e}}$ \\
\hline Maize Stover mix & $1.08^{\mathrm{e}}$ \\
\hline Maize Stover & $1.01^{\mathrm{e}}$ \\
\hline Maize cob & $0.75^{\mathrm{e}}$ \\
\hline Grand Mean & 1.24 \\
\hline $\mathrm{CD}(\mathrm{P} \leq 0.05)$ & 0.23 \\
\hline $\mathrm{CV}(\%)$ & 12.66 \\
\hline F test & $* *$ \\
\hline
\end{tabular}

\section{Effect of different substrates on stipe length of oyster mushroom}

Stipe length was significantly differed on the different substrates compositions. Among the tested substrates composition the highest stipe length was recorded on lentil straw mix $(4.40 \mathrm{~cm})$ followed by rice straw $(4.33$ $\mathrm{cm})$ and lentil straw $(4.26 \mathrm{~cm})$ while the lowest stipe length $(2.60 \mathrm{~cm})$ was recorded on maize cob followed by wheat straw $(3.30 \mathrm{~cm})$. 
Agriways 8 (1) :1-8.2020

Table 6: Effect of different substrates on stipe length of oyster mushroom

\begin{tabular}{ll}
\hline Treatments & Stipe length $(\mathrm{cm})$ \\
& \\
\hline Lentil mix & $4.40^{\mathrm{a}}$ \\
Rice straw & $4.33^{\mathrm{a}}$ \\
Lentil straw & $4.26^{\mathrm{a}}$ \\
Maize straw mix & $4.17^{\mathrm{a}}$ \\
Maize Stover & $4.10^{\mathrm{a}}$ \\
Rice mix & $4.05^{\mathrm{a}}$ \\
Wheat straw & $3.30^{\mathrm{b}}$ \\
Wheat mix & $3.10^{\mathrm{bc}}$ \\
Maize cob & $2.60^{\mathrm{c}}$ \\
\hline Grand Mean & 3.81 \\
CD $(\mathrm{P} \leq 0.05)$ & 0.53 \\
CV $\%)$ & 9.74 \\
$\mathrm{~F}$ test & $* *$ \\
\hline$* *=$ Significant at 1\% level, Mean values within the same column that bear different superscript letters are significantly \\
different $\alpha<0.05)$, CV=Coefficient of variation and CD=Critical difference
\end{tabular}

Relation between yield attributes (cap diameter) and yield

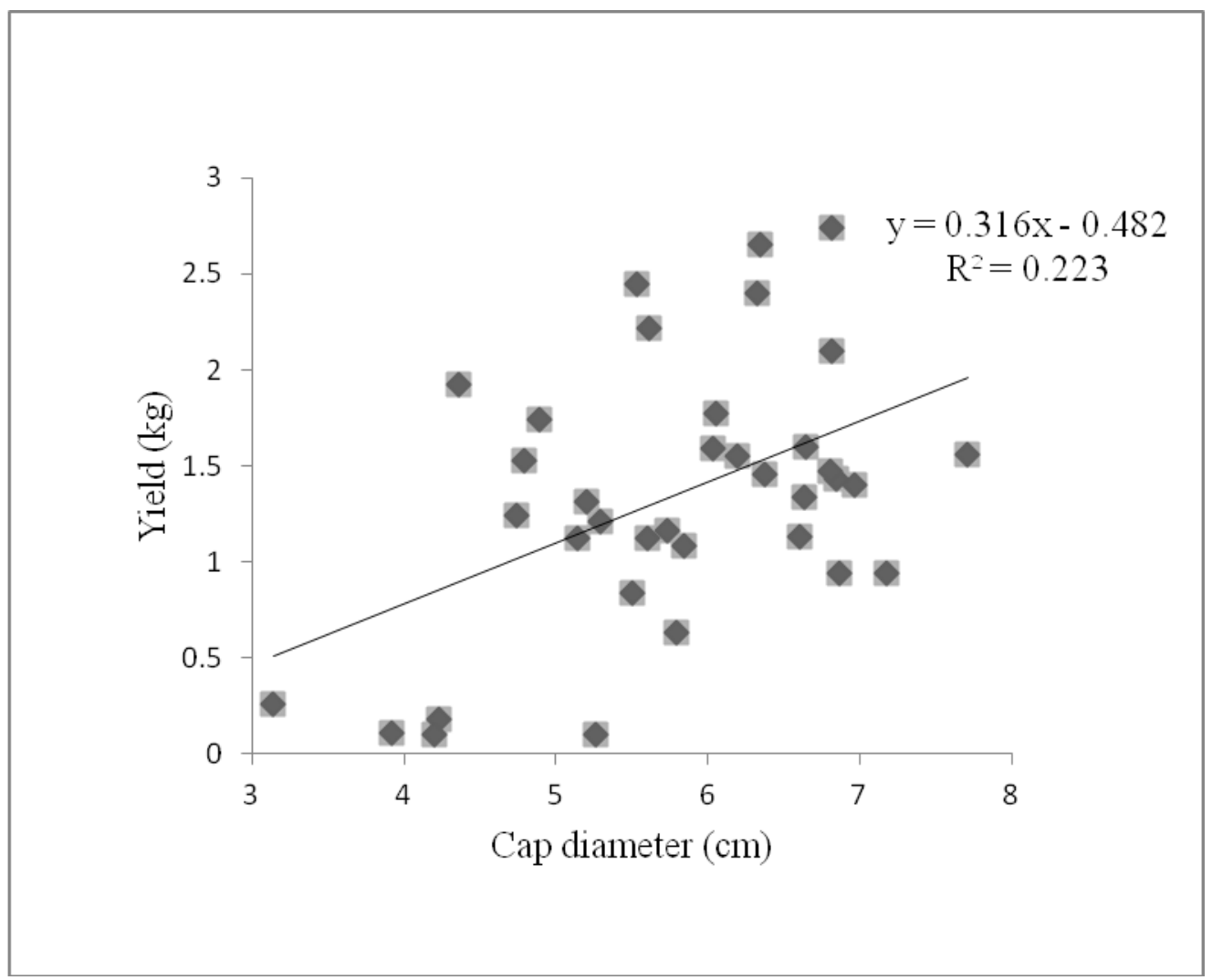

Figure 1: Relation between pileus diameter and yield

A positive linear relationship was observed between economic yield and cap diameter (Fig. 1). 
This suggests that yield is dependent on pileus diameter of effective fruiting body. More than $22 \%\left(\mathrm{R}^{2}=0.223\right)$ of variation in the yield may be explained by variation of pileus diameter and remaining by other factors.

\section{Discussion}

The days to complete colonization of oyster mushroom on different substrates was recorded and found significantly different among the substrates this might due to the variation in their chemical composition and C:N ratio as reported by Bhatti et al. (1987). The shortest period of colonization (22.5 days), first fruiting (25.5 days) and first harvesting (33 days) along with the highest yield $(2.47 \mathrm{~kg})$ was revealed by the substrate lentil straw which might be due to the presence of right proportion of hemicelluloses, lignin and carbon /nitrogen ratio on lentil straw. Quimio and Sardsud (1981) also supported the results, who found that the optimum carbon /nitrogen ratio for mycelial growth of $P$. ostratus was ranged from 40:1 to 90:1. Our findings was also supported by the Iqbal et al., (2005) and Kimenju et al., (2009), they also reported that the growth of the mushroom is considered to be dependent upon the performance of the substrates .Days to complete spawn running was ranged from 17 days to 30 days on different substrates where as Ahmed (1998) stated completion of spawn running in 17-20 days on different substrates. The result of present experiment are in agreement with the findings of Bugarski et al., (1994) who found that the first fruiting occurred on different days depending on substrates. Those substrates recording highest stipe length recorded the poor yield which was also supported by Zadrazil (1978) who reported that the quality of oyster mushroom depends on the length of stalk and the higher the length of stalk, the poor the quality of mushroom. The positive relationship was observed between the pileus diameter and the yield. The lowest yield was recorded on corn cobs.

\section{Conclusion}

From the research study, it is concluded that the substrate source affects greatly the performance and growth of oyster mushroom and lentil straw is more efficient for the production of oyster mushroom (Pleurotus ostreatus), as compared to rice straw which is very common in practice and other different substrates. Length and diameter of stipe, pileus diameter and spawn running duration were the most important yield attributing character of mushroom. Rice straw mix with maize cob is also more efficient as compared to rice straw only for the production of oyster mushroom.

\section{Acknowledgement}

The authors would like to acknowledge Prithu Technical College for providing materials and site for this study. They are thankful to their friends for their help and support throughout the research period.

\section{References}

Ahmed S. 1998. Development of mushroom varieties suitable for rural level in Bangladesh. Report presented in BARC. Annual Review Programme. pp. 72-73.

Bhatti MA, Mir FA and Siddiq M. 1987. Efect of different bedding materials on relative yield of oyster mushroom in the successive flushes. Pak $J$ Agrc. Res. 8:256

Buah JN, Van der Puije GC, Bediako EA, Abole EA and Showemimo F. 2010. The Growth and Yield Performance of Oyster Mushroom (Pleurotus ostreatus) on Different Substrates. Biotechnology, 9: $338-34$

Bugarski D, Gvozdenovic D, Takae A and Cervenski J. 1994. Yield and yield components of different strains of oyster mushroom. Savremena poljoprivreda (Yugoslavia), 42 (1): 314-318.

Celik Y. and Pekker K. 2009. Benefit/Cost analysis of mushroom production for diversification of income in developing countries. Bulgarian Journal of Agricultural Science, 15(3): 228-237.

Chang ST. 1999. World production of cultivated edible and medicinal mushrooms in 1997 with emphasis on Lentinus edodes (Berk). International Journal of Medicinal Mushrooms, 25(01): 291-300.

Gomez KA and Gomez AA.1984. Statistical procedures for agricultural research.2nd edn. International Rice Research Institute, College, Laguna, pp. 680.

Iqbal SM, Rauf CA and Sheik MI.2005.Yield performance of oyster mushroom on different substrates. International Journal of Agriculture Biology, 7(06): 900-903.

Ju HY.1994. Oyster mushroom cultivation. Department of Plant science, Nova Scotia Agricultural College. Canada. pp. 1-3.

Khare KB, Mutuku JM, Achwania OS and Otaye DO. 2010. Production of two oyster mushrooms, Pleurotus sajor-caju and P. florida on supplemented and un- supplemented substrates. International Journal of Agriculture and Applied Science, 6(04): 4-11.

Kimenju JW, Odero GOM, Mutitu EW, Wachira PM, Narla RD and Muiru WM. 2009. Suitability of locally available substrates for oyster mushroom (Pleurotus ostreatus) cultivationin Kenya. Asian J. Plant Sci., 8: 510-514 
Kong W. 2004. Oyster Mushroom Cultivation (Descriptions of Commercially Important Pleurotus species). Mushroom Growing Handbook 1, Mushworld 54-61.

Kurtzman, R.H. Jr., 1976. Nutrition of Pleurots sapidus: Effects of lipids. Mycologia, 68: 286-295. Direct Link

Mondal SR, Rehana MJ, Noman MS and Adhikary SK. 2010.Comparative Study on Growth and Yield Performance of Oyster Mushroom (Pleurotus florida) on Different Substrates. Journal of Bangladesh Agricultural University, 8(2): 213-220.

Nadir HA, Ali AJ and Muhammed GA. 2016. Determination of Yield and Quality of Oyster Mushroom (Pleurotus florida) Using Different Substrates in Halabja, Kurdistan. Plant Production, 7: 787-790.

Oei P.1996. Mushroom Cultivation with Special Emphasis on Appropriate Techniques for Developing Countries. 2nd Edn., Backhuys, Amsterdam, The Netherlands, pp: 111-122

Onyango BO, Palapala VA, Arama PF, Wagai SO and Gichumu BM. 2011. Sustainability of selected supplemented substrates for cultivation of Kenyan native wood ear mushrooms (Auricularia auricula). Am. J. Food. Technol., 6: 395-403.

Pokhrel CP, Kalyan N, Budathoki U and Yadav RKP. 2013. Cultivation of Pleurotus sajor-caju using different agricultural residues. International Journal of Agricultural Policy and Research, 2:19-23.

Quimio TH and Sardsud U. 1981. Nutritional requirements of Pleurotus ostreatus (Fr). Philippine Agr, 64(1):79-89.

Sher H, Yemeni MA and Bahkali AH. 2010. Effect of environmental factors on the yield of selected mushroom species growing in two different agro ecological zones of Pakistan. Saudi Journal of Biological Sciences, 17(4): 321-326.

Sher H, Al-Yemeni M and Khan K. 2011. Cultivation of the oyster mushroom (Pleurotus ostreatus (Jacq.) in two different agro ecological zones of Pakistan. African Journal Biotechnology, 10 (03): 183-188.

Zadrazil F. 1978. Cultivation of Pleurotus. The biology and cultivation of edible mushrooms by S.T. Chang and W.A. Hayes (eds). Academic press INC. Orlando, Florida.1:62. 